\title{
STUDI KEMAMPUAN GURU KIMIA SMA LULUSAN UNY DALAM MENGEMBANGKAN SOAL UAS BERBASIS HOTS
}

\author{
Dodi Iskandar ${ }^{1)}$, Senam ${ }^{2)}$ \\ Politeknik Negeri Pontianak Kalimantan Barat ${ }^{1)}$, Universitas Negeri Yogyakarta ${ }^{2)}$ \\ dodi.iskandar2011@yahoo.com ${ }^{1)}$, senamkw@yahoo.com ${ }^{2)}$
}

\begin{abstract}
Abstrak
Penelitian ini bertujuan untuk mengetahui kemampuan guru kimia SMA lulusan Prodi Pendidikan Kimia UNY dalam mengembangkan soal UAS berbasis HOTS. Jenis penelitian ini merupakan penelitian survei. Jumlah responden sebanyak 15 guru kimia dengan jumlah butir soal ujian akhir semester sebanyak 559 pertanyaan pada tahun 2013. Metode yang digunakan yaitu dokumentasi. Instrumen pengumpulan data yang dipakai berupa check list. Data yang dianalisis meliputi pengetahuan unsur C1 (remember), C2 (understand), C3 (apply) yang merupakan kategori lower order thinking skills (LOTS) dan C4 (analyze), C5 (evaluate) dan C6 (create) yang masuk kelompok higher order thingking skills (HOTS). Hasil penelitian menunjukkan bahwa kemampuan guru lulusan prodi Pendidikan Kimia UNY dalam mengembangkan soal berbasis HOTS sebesar $13,9 \%$; dengan rincian $\mathrm{C}_{4}$ sebesar $13,2 \%$; $\mathrm{C}_{5}$ sebesar $0,7 \%$ dan $\mathrm{C}_{6}$ sebesar $0,0 \%$.
\end{abstract}

Kata Kunci: Guru kimia, higher order thinking skills, soal

\section{A STUDY ON SENIOR HIGH SCHOOL CHEMISTRY TEACHERS ABILITY TO DEVELOP SEMESTER EXAMINATION MATERIALS BASED ON HIGHER-ORDER THINKING SKILLS}

\begin{abstract}
This study aimed to investigate senior high school chemistry teachers ability to develop semester examination materials based on higher-order thinking skills. This kind of research was a survey. A number of respondents were 15 chemistry teachers with 559 questions of semester final examination in year 2013. The used methods was documentation. This research used a document check list as an instrument to collect data. The analyzed data were C1 (remember), C2 (understand), C3 (apply) that included lower order thinking skills (LOTS), C4 (analyze), C5 (evaluate) and C6 (create) which classified to higher order thingking skills (HOTS). The results of the study was senior high school chemistry teachers ability to develop a semester examination material based on higher order thinking skills is 13,9\%, which consists of $C_{4} 13.2 \%$; $C_{5} 0.7 \%$ and $C_{6} 0.0 \%$.
\end{abstract}

Key words: chemistry teacher, higher order thinking skills, questions 


\section{PENDAHULUAN}

Kualitas guru menjadi bagian sangat penting dalam kemajuan suatu negara. Finlandia merupakan negara yang beralih dari negara industri agraris tradisional menjadi negara maju yang perekonomiannya ditopang oleh ilmu pengetahuan berbasis inovasi teknologi. Kemajuan tersebut disebabkan faktor kualitas guru yang telah disiapkan dengan sebaik-baiknya sebelum mereka mengajar (Sahlberg, 2010, p.2). Data Balitbang Depdiknas (2008) menunjukkan bahwa guru sekolah menengah atas (SMA) di Indonesia yang belum layak mengajar sebesar $34,71 \%$ di sekolah negeri dan 35,27\% di sekolah swasta (Muaddab, 2011).

Nuh (Kartini, 2011, p.8) menyatakan bahwa guru yang sudah mengikuti sertifikasi belum berhasil menunjukkan kompetensinya dari sisi pedagogi, profesional, sosial dan kepribadian. Keaktifan guru terlihat hanya menjelang sertifikasi, sedangkan setelahnya, kualitasnya mengalami penurunan. Penilaian kualitas guru di negara maju sejak 20 tahun terakhir telah menjadikan Kerangka Kualifikasi Nasional (KKN) sebagai standar.

Higher order thinking skills (HOTS) atau keterampilan berpikir tingkat tinggi merupakan bagian dari taksonomi Bloom hasil revisi yang berupa kata kerja operasional yang terdiri dari analyze (C4), evaluate (C5) dan create (C6) yang dapat digunakan dalam penyusunan soal. Guru harus memiliki pengetahuan dan keahlian untuk menunjang pekerjaannya, sehingga dapat mengembangkan keterampilan berpikir tingkat tinggi peserta didik tingkat SMA (Aydin \& Yilmaz, 2010, p.58).

Finlandia merupakan negara yang memiliki tingkat kemajuan yang tinggi dalam bidang pendidikan terutama pendidikan sains. Kondisi ini didukung oleh data bahwa soal matrikulasi kimia di Finlandia didominasi oleh soal berbasis HOTS sebesar $77 \%$ berdasarkan taksonomi Bloom Revisi (Tikkanen \& Aksela, 2012, p.258). Kondisi sebaliknya terjadi di Turki yang menempati urutan 73 berdasarkan perangkingan The Education for All Development Index tahun 2008 yang masih di bawah Indonesia dengan bentuk soal ujian kimia di SMA berbasis HOTS hanya sebesar 4\% (Karamustafaoglu et al., 2003, p.25).

Soal Ujian Akhir Semester (UAS) merupakan soal yang disusun oleh guru untuk menguji kemampuan proses kognitif peserta didik yang diseleng-garakan di akhir semester. Soal didefinisikan sebagai suatu instruksi atau pertanyaan yang memerlukan respon peserta didik dan aturan pemberian skor terhadap respon tersebut. Perbedaan mendasar bentuk soal terletak pada bentuk respon peserta didik, yaitu memilih jawaban (choose answer) atau menyusun jawaban (contructs answer). Secara anatomi dua tipe soal tersebut dapat dijelaskan pada Tabel 1. Essay dan multiple choice merupakan dua model soal yang sering digunakan untuk menilai kemampuan peserta didik pada domain kognitif.

Tabel 1. Perbedaan Anatomi Bentuk Soal

\begin{tabular}{clc}
\hline No & \multicolumn{1}{c}{$\begin{array}{c}\text { Bentuk Respon } \\
\text { Konstruk }\end{array}$} & $\begin{array}{c}\text { Bentuk Respon } \\
\text { Pilihan }\end{array}$ \\
\hline 1 & $\begin{array}{l}\text { Pertanyaan tertulis } \\
\text { Peserta didik memberi } \\
\text { respon }\end{array}$ & $\begin{array}{l}\text { Pertanyaan tertulis } \\
\text { Guru menyediakan } \\
\text { pilihan }\end{array}$ \\
3 & $\begin{array}{l}\text { Guru mengembangkan } \\
\text { sistem penilaian }\end{array}$ & $\begin{array}{c}\text { Peserta didik } \\
\text { memilih jawaban }\end{array}$ \\
4 & $\begin{array}{l}\text { Guru menggunakan } \\
\text { sistem penilaian }\end{array}$ & Penilaian objektif \\
\hline
\end{tabular}

(Haladyna, 1997, p.10)

Contoh berikut akan memperjelas perbedaan format essay dan multiple choice.

1) Sebutkan beberapa contoh penerapan sifat koloid dalam kehidupan sehari-hari! (format essay)!

2) Perhatikan rumus struktur karbon berikut! (format multiple choice)!

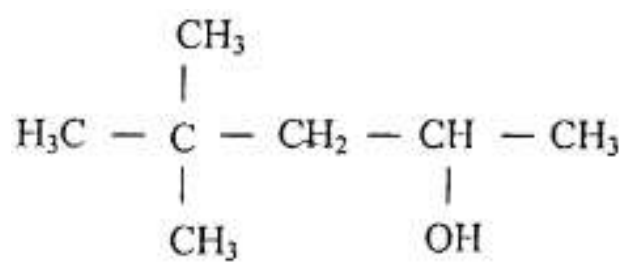

Nama IUPAC salah satu isomer senyawa di atas adalah.....

a) 4,4-dimetil-2-pentanol.

b) 3,3-dimetil-1-pentanol

c) 2,3,4- trimetil-1-pentanol

d) 4,4 - dimetil pentanal

e) 3,3-dimetil-2-pentanon

Format multiple choice dapat dibuat beberapa tipe yaitu:

\section{Konvensional}

Masing-masing soal hanya mengandung satu pernyataan yang benar. Contohnya:

a) Zat manakah yang bukan termasuk unsur nonlogam? 
(1) Emas

(2) Tembaga

(3) Karbon

(4) Timah

b) Pasangan manakah yang benar antara nama dan lambang unsur kimia berikut?
(1) Emas-Em
(2) Tembaga-Te
(3) Karbon-K
(4) Timah-Sn

\section{Alternative Choice}

Jenis soal alternative choice ini hanya menyediakan dua jenis pilihan jawaban, yaitu jawaban benar dan jawaban salah. Sistem penilaiannya sangat mudah. Contoh:

a) Manakah yang termasuk unsur golongan VII A di dalam sistem periodik unsur?

(1) Flour-Iodium

(2) Phospor-Chlorine

\section{Matching}

Jenis soal matching ini hanya menyediakan serangkaian pilihan yang dapat diterapkan pada dua item atau lebih. Jenis soal ini sangat cocok untuk mengukur pemahaman konsep, prinsip, dan prosedur. Contohnya:

Jodohkan pasangan kolom sebelah kiri (rumus senyawa) dengan kolom sebelah kanan (jenis ikatan), dengan cara memberikan nomor $(1,2$ atau 3) pada kotak kolom sebelah kiri yang sesuai.

\section{$1 . \mathrm{CaCl}_{2}$ 1. Ikatan Ion \\ $2 \mathrm{CO}_{2} \quad$ 2. Ikatan Kovalen}

$1 . \mathrm{HNO}_{3} \quad$ 3.Ikatan Kovalen Koordinasi

$2 \mathrm{O}_{2}$

$1 . \mathrm{FeCl}_{2}$

\section{True-False}

Format soal jenis true-false berupa pernyataan yang akan dijawab peserta didik dengan memberikan respon terhadap isi pernyataan dengan jawaban salah atau benar. Format ini tidak direkomendasikan karena dianggap memi- liki kecenderungan peserta didik merespon dengan jawaban salah.

\section{Pictorial Item Set}

Format soal ini dirancang berdasarkan fitur seperti grafik, tabel, foto, karya seni, atau bentuk visual lainnya yang diikuti rangkaian pertanyaan yang berkorelasi satu dengan yang lainnya. Format ini cocok untuk memasukkan soal higher order thinking skills yang mencakup berpikir kritis. Fitur yang bisa ditampilkan dapat diperoleh dari surat kabar, majalah dan sumber lain yang memuat grafik dan format pictorial item set lainnya.

\section{Problem-Solving Item Set}

Format problem-solving item set dianggap sebagai cara yang paling baik dalam mengukur keterampilan pemecahan masalah (problem solving). Format problem-solving item set menampilkan gambaran dalam bentuk uraian atau fitur seperti format lainnya yang kemudian diikuti serangkaian pertanyaan. Uraian atau fitur ditekankan berhubungan erat dengan kejadian kehidupan sehari-hari (Haladyna, 1997, pp.5058).

Anatomi soal multiple choice terdiri dari kalimat soal (stem), jawaban salah (disctractors), dan jawaban benar (key) seperti dicontohkan pada contoh berikut:

Unsur yang terletak pada

Golongan II A, periode 4

mempunyai nomor atom......

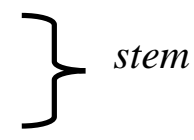

1. 40 (disctractors)

2. 24 (disctractors)

3. 20 (key)

4. 18 (disctractors)

5. 12 (disctractors)

(Haladyna, 1997, p.63).

Keterampilan berpikir merupakan gabungan dua kata yang memiliki makna berbeda, yaitu berpikir (thinking) dan keterampilan (skills). Berpikir merupakan proses kognitif, yaitu mengetahui, mengingat, dan mempersepsikan, sedangkan arti dari keterampilan, yaitu tindakan dari mengumpulkan dan menye-leksi informasi, menganalisis, menarik kesim-pulan, gagasan, pemecahan persoalan, mengevaluasi pilihan, membuat keputusan dan merefleksikan (Wilson, 2000, p.7).

\section{Kategori HOTS}

Dfes (Aksela, 2005, p.33) menyatakan bahwa keterampilan berpikir mencakup: (1) 
keterampilan mengolah informasi, (2) keterampilan berargumen, (3) keterampilan inkuiri, (4) keterampilan berpikir kreatif, serta (5) keterampilan mengevaluasi. Lai (2011, p.2) mendefinisikan berpikir kritis meliputi: (1) keterampilan menganalisis argumen, (2) keterampilan membuat kesimpulan dengan alasan deduktif dan induktif, serta (3) keterampilan mengevaluasi dan membuat keputusan.

King et al. (2013, p.1) mengkategorikan HOTS sebagai berikut: (1) berpikir kritis dan berpikir logis, (2) berpikir reflektif, (3) berpikir metakognitif, dan (4) berpikir kreatif. Cara mengevalusi HOTS peserta didik dapat ditempuh dengan cara mengukur melalui beberapa cara, yaitu (1) memilih (multiple-choice, matching, dan rank-order items), (2) menggeneralisasi (jawaban singkat, esai), dan (3) memberi alasan.

Bagarukayo et al. (2012, p.120) mendefinisikan HOTS meliputi: (1) membuat keputusan, (2) menyelesaikan masalah, (3) berpikir kritis, (4) menganalisis, (5) mensintesis, serta (6) menginterpretasi. Zohar \& Dori (2003, pp.145181) mengkategorikan HOTS menjadi: (1) berargumen konstruktif, (2) mengajukan pertanyaan ilmiah, (3) membuat perbandingan, (4) memecahkan masalah rumit nonalgoritma, (5) menggolongkan perbedaan pendapat, dan (6) mengidentifikasi asumsi yang tersirat.

Khan \& Inamullah (2011, pp.149-151) menyatakan bahwa keterampilan berpikir di dalam taksonomi Bloom terbagi menjadi dua, yaitu (1) keterampilan berpikir tingkat rendah, dan (2) keterampilan berpikir tingkat tinggi. Keterampilan berpikir dari taksonomi Bloom direvisi oleh Anderson dan dipublikasikan Tahun 2001. Pada awalnya taksonomi Bloom yang dipublikasikan pada tahun 1956 terdiri dari knowledge, understand, application, analysis, synthesis dan evaluation. Revisi yang dilakukan menggunakan dua dimensi, yaitu (1) dimensi pengetahuan (fakta, konsep, prosedur, metakognitif), dan (2) dimensi proses kognitif (remember, understand, apply, analyze, evaluate, dan create). Guru dapat menentukan dua dimensi dalam proses pembelajaran yang disesuaikan dengan kata kerja operasional dan materi pembelajaran (Reeves, 2006, p.297; Yang, et al., 2012, p.495).

Gilligan (2008, p.7) menyatakan bahwa taksonomi Bloom hasil revisi sangat berguna bagi guru untuk untuk mengembangkan keterampilan berpikir tingkat tinggi dalam pelaksanaan pembelajaran. Guru menggunakan kata kerja operasional yang berhubungan dengan keterampilan berpikir tingkat tinggi.

Boo (Aksela, 2005, p.4) menyatakan bahwa agar peserta didik memiliki keterampilan berpikir tingkat tinggi yang baik diperlukan pembelajaran yang mendukung. Sebagai contoh, peserta didik SMA di Finlandia yang mampu memahami konsep reaksi eksotermis dalam mata pelajaran kimia hanya sebesar $15 \%$. Fenomena tersebut karena pembelajaran pada saat itu belum berbasis HOTS. Pembelajaran berbasis HOTS sangat erat dengan perangkat pembelajaran. Saptorini (2010) menyatakan bahwa di kabupaten Demak terdapat 87,6\% guru kimia mengalami kesulitan dalam merancang dan menyampaikan pembelajaran.

Sesuai Permendiknas nomor 6 Tahun 2007 dinyatakan bahwa salah satu kompetensi inti guru pada dimensi pedagogi, yaitu dapat menyelenggarakan penilaian, dan evaluasi proses dan hasil belajar.

Penilaian merupakan proses pengumpulan dan pengolahan informasi untuk menentukan pencapaian hasil belajar peserta didik. Seorang pendidik dapat melakukan penilaian dengan baik jika didukung oleh instrumen penilaian. Instrumen penilaian yang baik merupakan instrumen yang dibuat dalam bentuk soal berbasis pengembangan HOTS (Devi, 2013).

Informasi mengenai kemampuan guru kimia SMA lulusan Prodi Pendidikan Kimia UNY dalam mengembangkan soal UAS berbasis HOTS sangat diperlukan untuk meningkatkan kualitas proses pembelajaran kimia di SMA.

\section{METODE}

\section{Jenis Penelitian}

Sesuai dengan tujuan yang telah diungkapkan, penelitian ini termasuk dalam penelitian survei. Penelitian ini difokuskan pada upaya untuk mengungkap kemampuan guru kimia SMA dalam mengembangkan soal UAS berbasis HOTS. Penelitian ini tidak memberikan perlakuan terhadap subjek penelitian.

\section{Waktu dan Tempat}

Penelitian ini dilakukan pada 15 lokasi sekolah setingkat SMA di Kotamadya Yogyakarta dan di Kabupaten Sleman yang memiliki guru Kimia lulusan Sarjana Pendidikan Kimia UNY. Penelitian dilaksanakan pada bulan Januari-Maret 2014. 


\section{Subjek Penelitian}

Subjek penelitian ini merupakan guru kimia SMA lulusan tahun 2001-2011 Prodi Pendidikan Kimia UNY.

\section{Prosedur}

Metode yang digunakan dalam penelitian ini yaitu dokumentasi.

\section{Instrumen, dan Teknik Pengumpulan Data}

Data hasil penelitian diperoleh dari hasil analisis terhadap soal UAS yang disusun oleh guru kimia SMA. Instrumen pengumpulan data yang dipakai, yaitu check list. Kandungan HOTS dalam soal UAS yang disusun guru diperoleh melalui metode dokumentasi dengan menganalisis masing-masing butir soal yang disusun didasarkan pada kategori HOTS berdasarkan taksonomi Bloom hasil revisi. Teknik pengumpulan data dengan menggunakan panduan. Untuk mengetahui soal UAS masuk dalam kategori LOTS atau HOTS menggunakan dimensi proses kognitif. Contoh cara menganalisis butir soal berdasarkan taksonomi Bloom hasil revisi disajikan pada Tabel 2.

Tabel 2. Dimensi Proses Kognitif Contoh Materi Kimia

\begin{tabular}{|c|c|c|}
\hline Kategori & Definisi & Contoh \\
\hline Mengingat (C1) & $\begin{array}{l}\text { Mengingat kembali pengetahuan relevan } \\
\text { yang bersumber dari memori waktu lama } \\
\text { (long term memory), seperti: mengenal, } \\
\text { menyebutkan }\end{array}$ & $\begin{array}{l}\text { Mengenal lambang unsur kimia, dan menyebut- } \\
\text { kan waktu penemuan kimia }\end{array}$ \\
\hline Memahami (C2) & $\begin{array}{l}\text { Membangun pengertian pesan instruksio- } \\
\text { nal mencakup lisan, tulisan, dan komuni- } \\
\text { kasi grafik (interpreting, exemplifying, } \\
\text { classifying, summarizing, inferring, } \\
\text { comparing, explaining) }\end{array}$ & $\begin{array}{l}\text { Menguraikan konsep kimia dengan ungkapan } \\
\text { sendiri, menyebutkan contoh senyawa organik, } \\
\text { menggolongkan jenis karbohidrat, menduga } \\
\text { struktur senyawa organik, membandingkan unsur } \\
\text { pada tabel periodik, menjelaskan arah reaksi }\end{array}$ \\
\hline $\begin{array}{l}\text { Mengaplikasikan } \\
\text { (C3) }\end{array}$ & $\begin{array}{l}\text { Menggunakan prosedur (executing, } \\
\text { implementing) }\end{array}$ & $\begin{array}{l}\text { Mempraktekkan penyulingan, menggunakan } \\
\text { hukum gas ideal }\end{array}$ \\
\hline $\begin{array}{l}\text { Menganalisis } \\
\text { (C4) }\end{array}$ & $\begin{array}{l}\text { Membagi materi menjadi bagian pokok } \\
\text { dan menentukan cara bagian tersebut } \\
\text { saling berhubungan satu sama lain dan } \\
\text { berhubungan dengan keseluruhan struktur } \\
\text { (differentiating, organizing, attributing) }\end{array}$ & $\begin{array}{l}\text { Mengidentifikasi unsur penting dari masalah, } \\
\text { menganalisis laporan penelitian kimia, } \\
\text { memberitahukan sikap penulis artikel kimia }\end{array}$ \\
\hline $\begin{array}{l}\text { Mengevaluasi } \\
\quad \text { (C5) }\end{array}$ & $\begin{array}{l}\text { Menyatakan pendapat berdasarkan kriteria } \\
\text { dan standar (checking, critiquing) }\end{array}$ & $\begin{array}{l}\text { Memeriksa rasionalitas pemecahan masalah, dan } \\
\text { mengkritisi perbedaan metode ilmiah }\end{array}$ \\
\hline Mengkreasi (C6) & $\begin{array}{l}\text { Menempatkan unsur bersama dengan } \\
\text { bentuk koherensi atau keseluruhan fungsi, } \\
\text { mengorganisir unsur ke dalam pola atau } \\
\text { susunan baru (generating, planning, } \\
\text { producing) }\end{array}$ & $\begin{array}{l}\text { Menghasilkan hipotesis, merencanakan metode } \\
\text { ilmiah, menulis karya ilmiah }\end{array}$ \\
\hline
\end{tabular}

(Tikkanen \& Aksela, 2012, p.260).

\section{Teknik Analisa Data}

Data yang diperoleh ditabulasikan berdasarkan kategori LOTS dan HOTS. LOTS terdiri dari $\mathrm{C} 1$ (remember), $\mathrm{C} 2$ (understand) serta $\mathrm{C} 3$ (apply). HOTS mencakup C4 (analyze), C5 (evaluate) dan C6 (create). Unsur lower order thinking skills, yaitu mengingat (remember), memahami (understand) dan mengaplikasikan (apply).

\section{HASIL DAN PEMBAHASAN}

Kemampuan guru kimia dalam mengembangkan soal Ujian Akhir Semester disajikan pada Tabel 4. Trend persentase dimensi kognitif taksonomi Bloom dari 559 butir soal yang dibuat oleh guru kimia dapat dilihat pada Gambar 1. 
Tabel 4.Kemampuan Guru Kimia dalam Mengembangkan Soal UAS

\begin{tabular}{cccc}
\hline No & Uraian & & Jumlah \\
\hline 1 & Responden & & 15 \\
2 & Butir Soal & & 559 \\
& & C1 & $155(27,7 \%)$ \\
3 & LOTS & C2 & $105(18,8 \%)$ \\
& & C3 & $221(39,5 \%)$ \\
& & C4 & $74(13,2 \%)$ \\
4 & HOTS & C5 & $4(0,7 \%)$ \\
& & C6 & $0(0 \%)$ \\
\hline
\end{tabular}

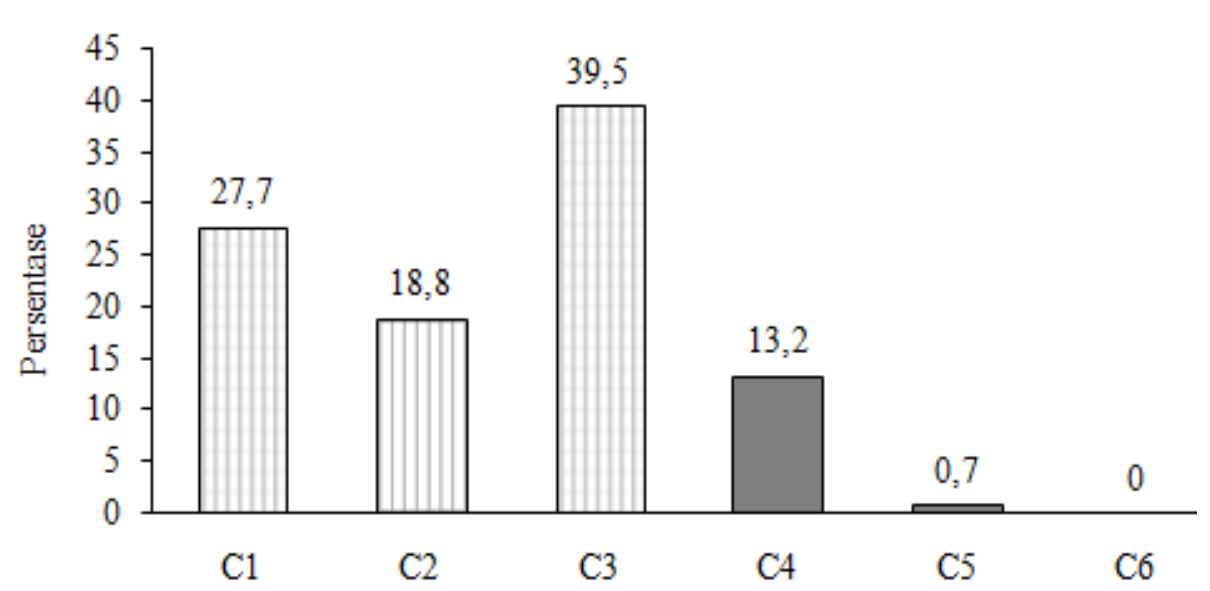

Gambar 1.Persentase Dimensi Kognitif Taksonomi Bloom Revisi dalam Soal UAS

Soal Ujian Akhir Semester yang dikembangkan guru kimia mengandung 13,9\% unsur higher order thinking skills dengan sebaran unsur menganalisis (analyze) atau $\mathrm{C} 4$ sebesar $13,2 \%$ dan mengevaluasi (evaluate) atau C5 sebesar $0,7 \%$. Hasil ini menunjukkan bahwa kemampuan guru kimia dalam mengembangkan soal UAS masih didominasi oleh unsur lower order thinking skills. Kemampuan berpikir tingkat tinggi peserta didik sangat dipengaruhi oleh pembelajaran. Untuk itu guru diharapkan dapat menerapkan pembelajaran berbasis HOTS yang mengedepankan unsur C4, C5 dan C6. Langkah ini sejalan dengan penelitian Percoski (2011, p.1) mengenai HOTS yang menyatakan bahwa pembelajaran berbasis HOTS akan lebih menghasilkan peserta didik dengan tingkat retensi yang lama, artinya memahami konsep kimia secara utuh dapat bertahan lebih lama dalam ingatan peserta didik. Ausubel et al. (Aksela, 2005, p.24) menyebutkan bahwa peserta didik dapat me-nunjukkan HOTS dalam konsep reaksi kimia disebabkan tiga faktor, yaitu pembelajaran bermakna (meaningful learning set), konsep pengetahuan awal peserta didik (student prior knowledge) dan kebermaknaan konsep baru yang melekat (inherent meaningfulness of a new concepts).

\section{SIMPULAN DAN SARAN}

\section{Simpulan}

Kemampuan guru kimia dalam mengembangkan soal UAS, yaitu kandungan HOTS dalam soal UAS sebesar 13,9\% yang terdiri dari menganalisis (C4) sebesar 13,2\%, dan mengevaluasi (C5) sebesar $0,7 \%$.

\section{Saran}

Perlunya penelitian kemampuan guru kimia SMA lulusan UNY dalam menyusun perangkat pembelajaran berbasis higher order thinking skill. 
Tabel 3.Contoh Analisis Jenjang Berdasarkan Dimensi Proses Kognitif Taksonomi Bloom Revisi

\begin{tabular}{|c|c|c|c|}
\hline No & $\begin{array}{ll} & \text { ButirSoal } \\
\end{array}$ & Jenjang & Kriteria \\
\hline 1 & $\begin{array}{l}\text { Larutan berikut yang diharapkan } \\
\text { menghantarkan listrik paling baik adalah: } \\
\text { a. Larutan glukosa } 2 \mathrm{M} \\
\text { b. Larutan asam cuka } 0,2 \mathrm{M} \\
\text { c. Larutan asam cuka } 2 \mathrm{M} \\
\text { d. Larutan asam sulfat } 0,2 \mathrm{M} \\
\text { e. larutan asam sulfat } 2 \mathrm{M} \\
\text { Sumber : } \\
\text { Naskahsoal ulangan kenaikan kelas tahun pelajaran 2009/2010 SMA } \\
\text { Negeri } 8 \text { Yogyakarta, mata pelajaran kimia kelas X }\end{array}$ & $\mathrm{C}$ & Memahami \\
\hline 2 & 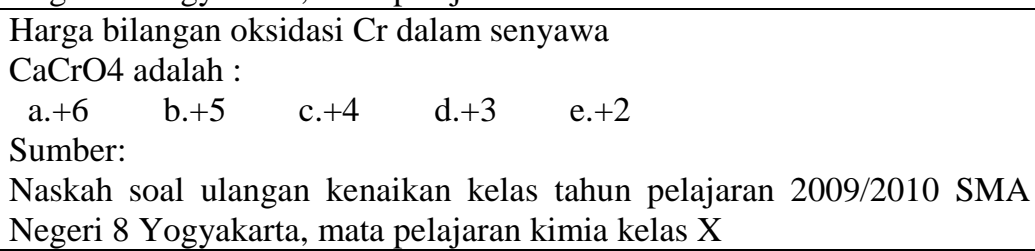 & $\mathrm{C} 3$ & Mengaplikasikan \\
\hline 3 & $\begin{array}{l}\text { Senyawa cis 3-metil heksena dan trans 3-metilheksena merupakan } 2 \\
\text { senyawa yang saling berisomeri: } \\
\begin{array}{lll}\text { a. Posisi } & \text { b. Rantai } & \text { c. Geometri } \\
\text { d. Optis } & \text { e. Struktur }\end{array} \\
\text { Sumber : } \\
\text { Naskah soal ulangan kenaikan kelas tahun pelajaran 2009/2010 SMA } \\
\text { Negeri } 8 \text { Yogyakarta, mata pelajaran kimia kelas X }\end{array}$ & $\mathrm{C} 2$ & Memahami \\
\hline 4 & $\begin{array}{l}\text { Gambar berikut adalah kurva titrasi. Satu kurva menggambarkan titrasi } \\
\text { asam asetat dan kurva lainnya menunjukkan titrasi asam nitrat dengan } \\
\text { larutan natrium hidroksida. } \\
\text { a) Kurva manakah yang merupakan titrasi asam nitrat? } \\
\text { b) Titrasi manakah yang menunjukkan larutan buffer terbentuk? } \\
\text { c) Mengapa nilai pH dapat berbeda pada titik ekivalen titrasi? } \\
\text { d) Mengapa kurva dapat menyatu setelah titik ekivalen? }\end{array}$ & $\mathrm{C} 4$ & Menganalisis \\
\hline
\end{tabular}

\section{Daftar Pustaka}

Aksela, M. (2005). Supporting meaningful chemistry learning and higher order thinking through computer assisted inquiry: A design research approach. academic Dissertation. Chemistry Education Center Department of Chemistry University of Helsinki Finland.

Aydin, N., Yilmaz, A. (2010). The effect of constructivist approach in chemistry education on students' higher order cognitive skills. Journal of Education, (39), 57-68.

Bagarukayo, E. (2012). Thenimpact of learning driven constructs on the perceived higher ordercognitive skills improvement: Multimedia vs. text. International Journal of Education and Development using Information and Communication Technology, (8), pp.120-130.

Devi, P.K. (23 Januari 2012). Pengembangan soal "higher order thinking skill" dalam pembelajaran IPA SMP/MTs. Diakses 23 September 2013 dari www.p4tkipa.net/data-jurnal/HOTs. Poppy.pdf.

Gilligan, M.E. (2007). Traditional versus alternative assessments: which type do high school teachers perceive as most effective in the assessment of higherorder thinking skills?. A Dissertation. 
Presented to the Faculty of the Graduate School of Saint Louis University in Partial Fulfillment of the Requirements for the Degree of Doctor of Philosophy.ProQuest LLC.

Haladyna, T.M. (1997). Writing test items to evaluate higher order thinking skills. Bosotn: A Pearson Education Company.

Karamustafaoglu, S., et.al, (2003). Analysis of turkish high-school chemistry-examination questions according to blooms taxonomy.chemistry education. Research and Practice, (4), pp.25-30.

Kartini, T. (2011). Faktor-faktor yang mempengaruhi kompetensi profesional guru di SMK N 1 Losarang Kabupaten Indramayu. Tesis tidak diterbitkan, Universitas Indonesia, Jakarta.

Khan,W.B. \& Inamullah, H.M. (2011). A Study of Lower-order and Higher-order Questions at Secondary Level. Canadian Center of Science and Education Asian Social Science,(7), 9.

King, F.J., Goodson, L.,\& Rohani, F. (2013). Higher order thinking skills. Diakses tanggal 11 Juli 2013 dari http://www.cala.fsu.edu/files/higher_ord er_thinking_skillsPdf.

Lai, E.R. (2011). Critical thinking: A literature review. research report. Diakses 29 Agustus 2013 dari http://www.pearson assessments.com/hai/images/tmrs/critica 1 ThinkingReviewfinal.pdf.

Muaddab, H. (2011). Jaminan mutu dalam sertifikasi guru. Diakses 27 Juli 2013 http://Netsains.Net/2011/10/JaminanMutu-Dalam-Sertifikasi-Guru/.

Percoski, T.D. (2011). The use of higher order cognitive strategies to improve student understanding of high school chemistry concepts. Thesis of Master of Science Education. Montana State University Bozeman, Montana. Diakses 29 Agustus 2013 dari http://scholarworks.montana.edu/xmlui/
bitstream/handlen/1/2039/PercoskiT081 1.pdf? Sequence $=1$.

Reeves, T.C. (2006). How do you know they are learning?: the importance of alignment in higher education. Int. J. Learning Technology, 2, (4):297.

Sahlberg, P. (2010). The secret to Finland's success:Educating teacher. Diakses 27 Juli 2013 dari www.edpolicy. stanford.edu.

Saptorini.(2010). Pengembangan model pembelajaran berbasis inkuiri sebagai upaya peningkatan kemampuan inkuiri guru kimia di Kabupaten Demak. Diakses 27 Juli $2013 \quad$ dari http://journal.unnes.ac.id/nju/index.php/ rekayasa/article/download.

The Education For All Development Index. (2011). Education for all global monitoring reports. Diakses 2 Oktober 2013 dari www.unesco.org/new /fileadmin/gmr2011-efa-developmentindex.pdf.

Tikkanen, G., \& Aksela, M. (2012). Analysis of Finnish chemistry Matriculation Examination questions according to Cognitive Complexity. Nordina Journal, (8), 258-268.

Wilson,V. (2000). Education forum on teaching thinking skills. edinburgh. report, the scottish council for research in education. Diakses 20 Agustus2013 dari http://www.scie-

socialcareonline.org.uk/Repository /fulltext/educthinking.pdf.

Zohar, A., \& Dori,Y.J. (2003). Higher order thinking skills and low-achieving students: Are they mutually exclusive? The Journal of The Learning Sciences, (12), pp.145-181.

Yang, C. (2012). Applications of chemical learning evaluation based on Bloom's taxonomy of educational objectives. $J$. Chem. Eng. (1), p.495. 